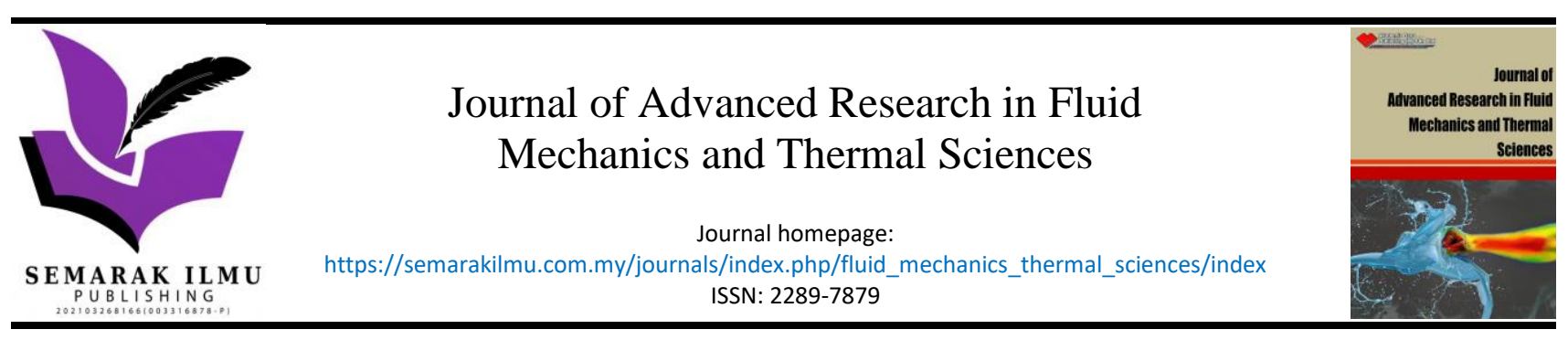

\title{
Greenhouse Gas Emission Intensity Assessment for Power Plants in Peninsular Malaysia
}

\author{
Sazalina Zakaria ${ }^{1,2,{ }^{*},}$, Radin Diana R. Ahmad ${ }^{1,2}$, Ahmad Rosly Abbas $^{1}$, Mohd Faizal Mohideen Batcha ${ }^{2}$ \\ 1 Built Environment and Climate Change Unit, Generation and Environment Department, TNB Research Sdn. Bhd., 43000 Kajang, Selangor, \\ Malaysia \\ 2 Faculty of Mechanical and Manufacturing Engineering, University Tun Hussein Onn Malaysia (UTHM), Parit Raja, Batu Pahat, Johor, Malaysia
}

\section{ARTICLE INFO}

\section{Article history:}

Received 29 May 2021

Received in revised form 10 September 2021

Accepted 19 September 2021

Available online 25 October 2021

Keywords:

Carbon Footprint; Greenhouse Gas;

Electricity Generation; Mitigation

Measures

\section{ABSTRACT}

\begin{abstract}
The power sector has been playing a vital role in the industrialization, societal and economic development of a nation. In Malaysia, the total power generation for 2014 is $147,480 \mathrm{GWh}$ and eventually accounts for $54 \%$ of total carbon emissions for that year alone. A study was conducted to quantify the greenhouse gas emission from stationary combustion from several power plants in Peninsular Malaysia, followed by proposal for the emission reduction strategies. For the GHG emissions assessment, the Greenhouse Gas Protocol: A Corporate Accounting and Reporting Standard and Intergovernmental Panel on Climate Change (IPCC) methodologies was adopted. Based on this study, the highest GHG emission intensity were from coal power plants which ranged from $0.67-0.85 \mathrm{tCO}_{2} / \mathrm{MWh}$. The GHG emission intensity for natural gas power plants ranged from $0.38-0.78 \mathrm{tCO}_{2} / \mathrm{MWh}$. The overall $\mathrm{GHG}$ emission intensity for all power plants studied was estimated to be $0.54 \mathrm{tCO}_{2} / \mathrm{MWh}$. The large variations in $\mathrm{CO}_{2}$ emissions per MWh of electricity generated in fossil fuel power plants were due to differences in generation efficiency, fuel selection, technology, and plant age. In supporting Malaysia's conditional commitment of $45 \%$ GHG emissions intensity reduction target against the country's GDP, the emission reduction strategies up to 2025 were assessed using three key scenarios namely Business-As-Usual (BAU), Planning (PLAN) and Ambitious (AMB). Based on the analysis, the projection indicates that the emissions intensity for the power sector is about $0.79 \mathrm{tCO}_{2} / \mathrm{MWh}, 0.49 \mathrm{tCO}_{2} /$ $\mathrm{MWh}$, and $0.44 \mathrm{tCO}_{2} / \mathrm{MWh}$ under the BAU, PLN AMB scenarios respectively. Finally, GHG emission reduction potentials were also outlined in this paper.
\end{abstract}

\section{Introduction}

Energy consumption has a strong correlation with the economic growth and human development index. Higher levels of energy are needed to fuel infrastructure development and high economic activity, especially in countries like Malaysia with a high share of manufacturing and services [1]. Consequently, the GDP of Malaysia is expected to grow at $6 \%$, bringing in higher standards of living

\footnotetext{
* Corresponding author.

E-mail address: sazalina.zakaria@tnb.com.my
}

https://doi.org/10.37934/arfmts.88.2.1426 
and improved the well-being of its population and is expected to inevitably move to higher levels of energy use with an increase in energy requirements [2].

With economic progress, the Malaysian economy is becoming increasingly energy intensive. This scenario reflected in the energy intensity of the country which increased from about 6 tonnes of oil equivalent (toe)/RM Million in 1990 to 62 toe/RM Million in 2016. Also, the electricity generation capacity in Malaysia has increased 2.1 times from 13,824 MW in 2000 to 33,090 MW in 2016 at an average annual growth rate of $9.6 \%$ [3]. The total electricity produced in the year 2016 was 156,665 GWh, and the electricity consumption per capita rose from 3,099 kWh in 2005 to 4,553 kWh in 2016. As far as the fuel mix is concerned, $46.0 \%$ produced from coal, $39.7 \%$ from natural gas, $13.3 \%$ from hydro, $0.7 \%$ from diesel and $0.4 \%$ from renewables [4].

The expanding energy demand is expected to cause an increase in the anthropogenic greenhouse gases (GHG) in Malaysia. In 2014 the total anthropogenic GHG emissions for Malaysia was 317.63 $\mathrm{MtCO}_{2}$ eq. Where energy sector accounted for $80 \%$ share of the total, followed by the land use, land use change and forestry sector (13\%), waste sector (12\%), industrial processes $(6 \%)$ and agriculture (3\%). Within the energy sector, the power generation sector was the highest emitter of $\mathrm{CO}_{2}$ eq. $(47 \%)$, followed by the transportation sector (29\%), manufacturing industries $(21 \%)$ and the remaining contributors were from other sectors (commercial, residential and agriculture) (3\%) [5].

This situation was due to the high dependency of the energy sector on fossil fuels. Also, the trend shows that Malaysia's energy and emissions intensity have been steadily increasing, and it is expected the GHG emissions continue to rise in tandem with the growing demand for fossil fuel, particularly in the energy sector. Thus, the increasing trend of fossil fuel consumption in electricity generation particularly coal will contradict with the National goal to reduce the emissions intensity by $45 \%$ by 2030 [6].

It is important for the power sector to account for their emissions as the first step towards managing their carbon emissions, followed by taking appropriate mitigation actions. The potential of energy and GHG emissions reduction for other sectors such as construction, manufacturing, and transport have been studied by several researchers. For example, under the construction sector, Saba et al., 2018 suggested that low energy traditional method of construction (TMC) of stabilizing clay block can potentially reduce carbon dioxide $\left(\mathrm{CO}_{2}\right)$ emissions [7]. Therefore, this study aims to assess the relative of $\mathrm{CO}_{2}$ emissions with fuel consumption from electricity generations and quantify the potential $\mathrm{CO}_{2}$ mitigation. This study is also needed as an input for the policymaker to forms a strategic plan and implementation framework to adopt the low carbon developments that decouple the energy consumption with GHG emissions.

\section{Methodology}

Methodologies for calculating GHG emissions were based mostly on 2006 IPCC Guidelines for National Greenhouse Gas Inventories (IPCC). In general, IPCC calculation methods consist of three tiers. Tier 1 is the simplest methodology whereas Tier 3 is the most complicated. The Tier 1 approaches generally use default emission factors that are not specific to any region, country or specific kind of equipment. Tier 2 approaches are more accurate than Tier 1 because they use default technology specific or default country-specific emission factors. Tier 3 approaches are even more accurate than Tier 2, usually because of a more detailed methodology related to the specific site, or technology or country, and may require onsite monitoring in some cases [8].

In this study, The Tier 1 approach was used for estimating $\mathrm{CO}_{2}$ emissions to assess $\mathrm{GHG}$ emissions from stationary combustion, and the Tier 3 approach for estimating methane $\left(\mathrm{CH}_{4}\right)$ and nitrous oxide $\left(\mathrm{N}_{2} \mathrm{O}\right)$ emissions for power plants. The Tier 2 approach was only available for the calculation of $\mathrm{CO}_{2}$ 
emission for coal. However, this approach does not apply to the $\mathrm{CO}_{2}$ emission assessment in this study because Malaysia is yet to have a country-specific emission factor for fuel combustion [5]. The Tier 3 approach used for $\mathrm{CH}_{4}$ and $\mathrm{N}_{2} \mathrm{O}$ emissions due to their dependency on combustion technology.

\subsection{List of Power Plants}

Under this study, ten gas and four coal power plants involved in the greenhouse gas (GHG) emissions assessment with a total installed capacity of 12,925 MW as listed in Table 1 below.

Table 1

List of Power Plants $[9,10]$

\begin{tabular}{llll}
\hline Plant & Fuel & Type & Capacity (MW) \\
\hline G1 & Gas & CCGT & 1,136 \\
G2 & Gas & CCGT & 836 \\
G3 & Gas & OCGT & 625 \\
G4 & Gas & OCGT & 330 \\
G5 & Gas & CCGT & 729 \\
G6 & Gas & CCGT & 1,409 \\
C1 & Coal & Thermal & 2,070 \\
C2 & Coal & Thermal & 1,010 \\
G7 & Gas & CCGT & 1,071 \\
G8 & Gas & CCGT & 384 \\
G9 & Gas & CCGT & 275 \\
C3 & Coal & Thermal & 1,000 \\
G10 & Gas & CCGT & 564 \\
C4 & Coal & Thermal & 1,486 \\
\hline
\end{tabular}

\subsection{Energy Content Calculations for Power Plants}

The emission factors for Tier 1 and Tier 3 methods were based on the energy content of the fuels. The energy content of fuels combusted calculated by multiplying the mass or volume of fuels consumed by the net calorific value (known alternatively as the lower heating value). The lower heating value is needed since the emission factors were calculated based on lower heating values. Some sites also provided fuel consumption data based on energy consumed rather than volume consumed. All energy values calculated using gross calorific values (GCVs) were converted to reflect the net calorific value (NCV) of the fuel. The energy content of fuels was calculated by simply multiplying the NCV of the fuel by the mass or volume of the fuel.

Energy from Fuel $=$ Mass or Volume of Fuel $\times$ NCV

Since most of the data from power plants used GCV instead of NCV, the GCV value converted to NCV value before use. If the sites provided fuel consumption data in terms of energy consumed based on GCVs, then this energy consumption data were converted too. The conversion of calorific values or energy values was made using the equation below.

NCV $=$ GCV X ( $1-\%$ of Moisture Content) or NCV based Energy Content = GCV based Energy Content x (1-\% Moisture Content)

If percentage moisture content data was not available then, the percentage of moisture content was assumed to be $10 \%$ for gaseous fuels and $5 \%$ for liquid or solid fuels [11]. 


\section{$2.3 \mathrm{CO}_{2}$ Emission Using Tier 1 Approach}

Table 2 lists the default emission factors from IPCC 2006, for diesel oil, residual fuel oil, coal, and natural gas. $\mathrm{CO}_{2}$ emissions can be estimated with high accuracy using the Tier 1 default emission factors because $\mathrm{CO}_{2}$ emission factors are dependent on the carbon content of the fuel and not the combustion technology of the equipment.

Table 2

IPCC 2006 Default Emission Factors for Stationary Combustion

\begin{tabular}{ll}
\hline Fuel Type & $\begin{array}{l}\mathrm{CO}_{2} \text { Default Emission Factors } \\
\text { (kg of GHG per TJ on a Net Calorific Basis) }\end{array}$ \\
\hline Gas/Diesel Oil & 74,100 \\
Residual Fuel Oil & 77,400 \\
Coking Coal & 94,600 \\
Other Bituminous Coal & 94,600 \\
Sub-Bituminous Coal & 96,100 \\
Natural Gas & 56,100 \\
\hline
\end{tabular}

The GHG emissions from stationary combustion were calculated using the equation below:

Emissions $_{\mathrm{GHG}, \text { fuel }}=$ Fuel Consumption fuel $\mathrm{X}$ Emission Factor ${ }_{\mathrm{GHG}}$, fuel

where,

Emissions $\mathrm{GHG}_{\text {, fuel }}=\mathrm{GHG}$ Emissions by type of fuel (kg GHG)

Fuel Consumption fuel $_{\text {f }}$ Amount of fuel combusted (TJ)

Emission Factor ${ }_{G H G}$, fuel $=$ Default emission factor of a given $\mathrm{GHG}$ by type of fuel $(\mathrm{kg}$ gas/TJ)

For $\mathrm{CO}_{2}$, it includes the carbon oxidation factor, assumed to be 1 .

\section{4 $\mathrm{CH}_{4}$ and $\mathrm{N}_{2} \mathrm{O}$ Emissions Using Tier 3 Approach for Power Plants}

In Tier 3, the following equation was used to estimate GHG emissions by technology (i.e., any device, combustion process or fuel property that might influence emissions):

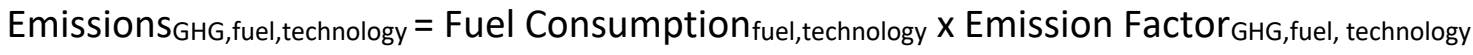

where,

Emissions $\mathrm{GHG}_{\mathrm{G}}$ fuel,technology = Emissions of a given $\mathrm{GHG}$ by type of fuel and technology (kg GHG)

Fuel Consumption fuel,technology $=$ Amount of fuel combusted by type of technology (TJ)

Emission Factor ${ }_{\mathrm{GHG}}$,fuel, technology $=$ Emission factor of a given $\mathrm{GHG}$ by type of fuel and technology (kg GHG/TJ) 
Table 3 below shows the technology-specific emission factors that listed in the IPCC 2006 guidelines for $\mathrm{CH}_{4}$ and $\mathrm{N}_{2} \mathrm{O}$ :

\section{Table 3}

IPCC 2006 Technology-Specific Utility Source Emission Factors

\begin{tabular}{llll}
\hline Basic Technology & Configuration & \multicolumn{2}{l}{$\begin{array}{l}\text { Emission Factors (kg of } \\
\text { GHG per TJ) } \\
\mathrm{CH}_{4}\end{array}$} \\
\hline Gas/Diesel Oil Boiler & Normal/Tangential Firing & 0.9 & $\mathrm{~N}_{2} \mathrm{O}$ \\
Residual Fuel Oil Boiler & Normal/Tangential Firing & 0.8 & 0.4 \\
Pulverized Bituminous & Dry Bottom, Wall Fired & 0.7 & 0.3 \\
Combustion Boilers & Dry Bottom, Tangentially Fired & 0.7 & 0.5 \\
& Wet Bottom & 0.9 & 1.4 \\
Natural Gas & Boilers & 1 & 1.4 \\
& Gas-Fired Gas Turbines >3MW & 4 & 1 \\
& Large Dual Fuel Engines & 258 & 1 \\
& Combined Cycle & 1 & $\mathrm{NA}$ \\
\hline
\end{tabular}

\subsection{GHG Emission Mitigation}

For the quantification of GHG mitigation, the emission reduction from large hydro and renewable energy was calculated using the CDM Executive Board (CDM EB) approved methodology 'ACM0002 Large-scale Consolidated Methodology: Grid-connected electricity generation from renewable sources. Ver.19.0' and 'AMS-1. D Grid Connected Renewable Electricity Generation. Ver.18.0' respectively. The CDM EB methodological tool determines the $\mathrm{CO}_{2}$ emission reduction due to the displacement of electricity that would be provided to the grid by more-GHG-intensive means $[12,13]$. This study also followed the 2006 IPCC Guideline for estimating hydropower reservoir emissions [14]. The IPCC 2006 prescribed Tier 1 methods for calculating the $\mathrm{CO}_{2}$ and $\mathrm{CH}_{4}$ from reservoirs, as follows:

\subsection{1 $\mathrm{CO}_{2}$ emissions}

The method to estimate the carbon stock change in aboveground living biomass due to land conversion to flooded land assumes that all aboveground biomass converted into $\mathrm{CO}_{2}$ in the first year following the conversion. The concentration was estimated using the equation below:

$\mathrm{CO}_{2}$ emissions $_{W W \text { flood }}=P \times E\left(\mathrm{CO}_{2}\right)_{\text {diff }} \times A_{\text {flood,totalsurface }}$

where,

$\mathrm{CO}_{2}$ emissionswwflood $=$ total $\mathrm{CO}_{2}$ emissions from flooded lands, Gigagrams $(\mathrm{Gg}) \mathrm{CO}_{2} / \mathrm{yr}$

$P=$ period, days (usually 365 for annual inventory estimates)

$E\left(\mathrm{CO}_{2}\right)$ diff = averaged daily diffusive emissions, $\mathrm{Gg} \mathrm{CO}_{2}$ hectares (ha)/day

$A_{\text {flood, total surface }}=$ total flooded surface area, including flooded land, flooded lake and flooded river surface area, ha 


\subsection{2 $\mathrm{CH}_{4}$ emissions}

$\mathrm{CH}_{4}$ emissions were estimated using the following equation:

$$
\mathrm{CH}_{4} \text { emissions }_{W W \text { flood }}=P \times A_{\text {flood,totalsurface }}\left(E\left(\mathrm{CH}_{4}\right)_{\text {diff }}+E\left(\mathrm{CH}_{4}\right)_{\text {bubble }}\right)
$$

where,

$\mathrm{CH}_{4} e_{\text {missionswwflood }}=$ total $\mathrm{CH}_{4}$ emissions from flooded lands, $\mathrm{Gg} \mathrm{CH}_{4} / \mathrm{yr}$

$P=$ period, days (usually 365 for annual inventory estimates)

$E\left(\mathrm{CH}_{4}\right)_{\text {diff }}=$ averaged daily diffusive emissions, $\mathrm{Gg} \mathrm{CH}_{4}$ ha/day

$E\left(\mathrm{CH}_{4}\right)_{\text {bubble }}=$ averaged daily bubbles emissions, $\mathrm{Gg} \mathrm{CH}_{4}$ ha/day

$A_{\text {flood, total surface }}=$ total flooded surface area, including flooded land, flooded lake and flooded river surface area, ha

\subsection{3 $\mathrm{N}_{2} \mathrm{O}$ emissions}

Tier 1 method for estimating $\mathrm{N}_{2} \mathrm{O}$ concerns the diffusion pathway only as emissions via bubbling is insignificant via the equation below.

$\mathrm{N}_{2} \mathrm{O}$ emissions $\left._{W W \text { flood }}=P \times E\left(\mathrm{~N}_{2} \mathrm{O}\right)_{\text {diff }}+A_{\text {flood,totalsurface }}\right)$

Where,

$\mathrm{N}_{2} \mathrm{O}$ emissionsww flood $=$ total $\mathrm{N}_{2} \mathrm{O}$ emissions from flooded lands, $\mathrm{Gg} \mathrm{N} \mathrm{N}_{2} \mathrm{O} / \mathrm{yr}$

$P=$ period, days (usually 365 for annual inventory estimates)

$E\left(\mathrm{~N}_{2} \mathrm{O}\right)_{\text {diff }}=$ averaged daily diffusive emissions, $\mathrm{Gg} \mathrm{N} \mathrm{N}_{2} \mathrm{O} / \mathrm{ha} /$ day

$A_{\text {flood, total surface }}=$ total flooded surface area, including flooded land, flooded lake and flooded river surface area, ha

\section{Table 4}

Default Emissions Factors (Ice-Free Period) for Tropical Setting

\begin{tabular}{llll}
\hline Climate & \multicolumn{2}{l}{$\begin{array}{l}\text { Diffusive Emissions }\left(\mathrm{kg} \mathrm{ha}^{-1} \mathrm{~d}^{-1}\right) \\
\mathrm{CO}_{2}\end{array} \mathrm{CH}_{4}$} & $\mathrm{~N}_{2} \mathrm{O}$ \\
\hline Tropical, wet & $0.64 \pm 330 \%$ & $60.4 \pm 145 \%$ & $0.05 \pm 100 \%$ \\
& Bubble Emissions & $\left(\mathrm{kg} \mathrm{ha}^{-1} \mathrm{~d}^{-1}\right)$ & \\
Tropical, wet & $\mathrm{Ns}$ & $2.83 \pm 45 \%$ & $\mathrm{Ns}$ \\
\hline
\end{tabular}

Note: $n s$ : not significant, $\mathrm{kg} / \mathrm{ha} / \mathrm{d}=\mathrm{Kg} / \mathrm{hectare} /$ day

The steps involved in the calculations are as follows:

i. Baseline Emissions $\left(B E_{y}\right)$. According to $C D M E B$, baseline emissions $\left(B E_{y}\right)$ is the $\mathrm{CO}_{2}$ emissions from electricity generation in fossil fuel-fired power plants that displaced due to the project activity. The methodology assumes that all project electricity generation above baseline levels would have generated by existing grid-connected power plants and the addition of new gridconnected power plants. The baseline emissions calculated as follows:

$B E_{y}=E G_{P J, y} \times E F_{\text {grid }, C M, y}$ 
where,

$B E_{y}=$ Baseline emissions in year $y\left(\mathrm{t} \mathrm{CO}_{2} / \mathrm{yr}\right)$

$E G_{P J, y}=$ Quantity of net electricity generation that produced and fed into the grid as a result of the implementation of the project activity in year $y(\mathrm{MWh} / \mathrm{yr})$

$E F_{\text {grid,CM,y }}=$ Combined margin $\mathrm{CO}_{2}$ emission factor for grid-connected power generation in year $y$ calculated using the latest version of "TOOL07: Tool to calculate the emission factor for an electricity system" ( $\mathrm{t} \mathrm{CO}_{2} / \mathrm{MWh}$ )

The grid emission factor $\left(E F_{\text {grid,CM,y }}\right), 0.694 \mathrm{tCO}_{2} / \mathrm{MWh}$ is used for this assessment. This grid emission factor sourced from 2014 Grid Connected Electricity Emissions Factor Study which conducted by Malaysian Green Technology Corporation [15].

ii. Project emission $\left(P E_{y}\right)$ is the emission in the presence of the project due to processes that release GHG to the atmosphere. These project emissions calculated using the following equation:

$P E_{y}=P E_{F F, y}+P E_{H P, y}$

where,

$P E_{y}=$ Project emissions in year $y\left(\mathrm{t} \mathrm{CO}_{2} \mathrm{e} / \mathrm{yr}\right)$

$P E_{F F, y}=$ Project emissions from fossil fuel consumption in year y $\left(\mathrm{t} \mathrm{CO}_{2} / \mathrm{yr}\right)$

$P E_{H P, y}=$ Project emissions from water reservoirs of hydropower plants in year $y\left(\mathrm{t} \mathrm{CO}_{2} \mathrm{e} / \mathrm{yr}\right)$

iii. Emission reductions calculated as follows

$E R_{y}=B E_{y}-P E_{y}$

where,

$E R_{y}=$ Emission reductions in year $y\left(\mathrm{t} \mathrm{CO}_{2} \mathrm{e} / \mathrm{yr}\right)$

$B E_{y} \quad=$ Baseline emissions in year $y\left(\mathrm{t} \mathrm{CO}_{2} / \mathrm{yr}\right)$

$P E_{y} \quad=$ Project emissions in year $y\left(\mathrm{t} \mathrm{CO}_{2} \mathrm{e} / \mathrm{yr}\right)$

The calculation of GHG mitigation for clean coal technology was done based on an estimation of how much GHG emissions reduction are possible through penetration of advanced clean coal technologies (CCTs) such as ultra-supercritical technologies (USC) for coal-based thermal power plants [16]. The steps involved in the calculations are as follows

i. The first step involves the calculation of the emission factors for Sub-critical, Super-Critical and Ultra-Super Critical Technology.

ii. For each period and scenario, the weighted average emission factor calculated.

iii. Total emissions for each period and scenario is calculated based on weighted average emission factor and the total generation of electricity. 
iv. Emission reduction is the difference of emissions between a particular scenario and the scenario without supercritical and ultra-supercritical technology penetration (with subcritical technology only).

Assumption

i. Scenario-I (absence of ultra-supercritical capacity)

ii. Scenario- II (ultra-supercritical technology penetration)

\section{Results}

The following were the results obtained with corresponding discussions.

\subsection{Power Plants GHG Emission}

In this study, it was observed that for power generation, $64 \%$ of GHG emission was due to coal consumption, followed by natural gas (36\%) and distillate (0.09\%). Table 5 below shows the GHG emissions from each of the power plants. From the overall power plant GHG emissions, Power Plant C1 was the highest emitter of GHGs followed by Power Plant G10C3 which fired by coal and natural gas.

\begin{tabular}{lll}
$\begin{array}{l}\text { Table } 5 \\
\text { Power Plants GHG Emissions }\end{array}$ \\
\hline Plant & Fuel & $\begin{array}{l}\text { GHG Emissions } \\
\left(\mathrm{mtCO}_{2} \text { ) }\right.\end{array}$ \\
\hline C1 & Coal & 15.08 \\
G10 & Gas & 7.34 \\
C4 & Coal & \\
C2 & Coal & 5.34 \\
G6 & Gas & 4.97 \\
G7 & Gas & 3.70 \\
G1 & Gas & 1.83 \\
G4 & Gas & 1.36 \\
G8 & Gas & 1.34 \\
C3 & Coal & 1.06 \\
G5 & Gas & 0.68 \\
G2 & Gas & 0.60 \\
G3 & Gas & 0.34 \\
G9 & Gas & 0.14 \\
\hline
\end{tabular}

When comparing among the natural gas power plants, Plant G6 was the highest emitter, followed closely by Plant G1. Plant G9 was the lowest emitter among all the thermal power stations, mainly due to its nature of the operation of the power plant, which is peaking plant. Due to the upward pressures on absolute emissions due to greater business volumes, a technology on Combined Cycle Gas Turbine (CCGT) plants were deployed and replaced with more efficient and economical CCGT plants. The latest CCGT development at Plant G7 runs on the latest gas turbine technologies (H-Class) enabling the plant to achieve generation efficiency of up to $60 \%$.

Plant C2 utilizes the latest coal-fired power plant which uses ultra-supercritical (USC) steam generation technology, resulting in lower coal consumption, higher efficiency, improved operational flexibility, and reduced emissions. This technology enables Plant C2 to operate at an efficiency exceeding $40 \%$ and generate more energy per unit of coal burned compared to the "subcritical" 
steam generation technology used by older plants within the complex. The thermal efficiency of a USC technology typically ranges from $30 \%$ to $40 \%$, with theoretical thermal efficiency up to $47 \%$. This study also involved a new generating unit (C3) which commissioned on 28 September 2017 with a $1,000 \mathrm{MW}$ capacity using the same high efficiency ultra-supercritical technology next to the Plant C2. The operational efficiencies of a coal power plant depend on multiple factors, key among which are fuel quality, generating technologies and generating capacity. Combination of Plant C1, C2 and C3 has now accounted for $20 \%$ of Peninsular Malaysia's total generation capacity.

It is significant to note that power plants do not decide for themselves how much electricity they need to generate. Whether a power plant runs or remains on standby depends on the National Load Dispatch Centre, NLDC. The NLDC monitors the grid demand and prioritizes the allocation of power generation according to the thermal efficiency of power plants in the country. Therefore a power plant cannot simply reduce its power generation to cut down on its GHG emissions; it has to generate energy in accordance with NLDC's allocation.

\subsection{GHG Performance of Emissions Intensity}

As stationary combustion from power generation is the main source of emissions, a measure of carbon performance in absolute greenhouse gas emissions per unit of electricity produced was performed to ascertain the GHG emissions for each fuel consumed and the power generation output as the main factor in the carbon intensity emissions. The following bar chart shows the GHG emission intensity for each thermal power plant covered in this study. It comprises natural gas fired with the combined cycle and open cycle technology and coal with subcritical and supercritical technology.

According to Figure 1, Power Plant G10C4 has contributed to higher GHG emissions intensity as it consumed coal and natural gas in its power generation followed by Power Plant $C$ which the power plant operated using open cycle gas turbine technology with operational efficiency at $26 \%$. Among the natural gas power plant, Power Plant G6 emit the lowest GHG emissions intensity as the power plant consists of four gas F-Class turbines and operate at an efficiency of more than $40 \%$. There are large variations in $\mathrm{CO}_{2}$ emissions per $\mathrm{kWh}$ of electricity generated in fossil fuel power plants due to differences in generation efficiency, fuel selection, technology, and plant age.

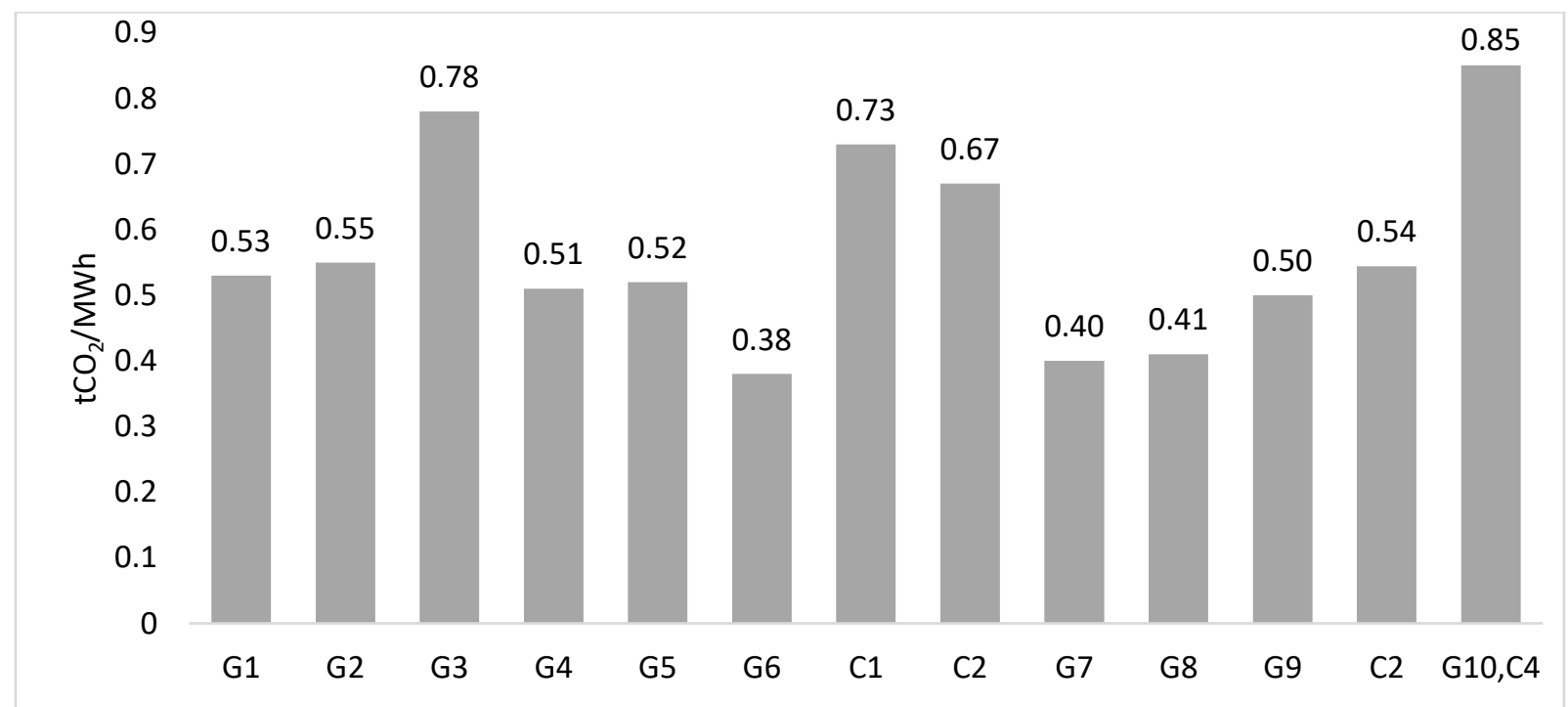

Fig. 1. GHG Emissions Intensity by Plant 


\subsection{GHG Emission Mitigation for Power Generation}

Power utilities are more aware of the problem of GHG emissions and its link to global climate change. Utilities also anticipate a carbon-constrained future and want to prepare for this operational constraint by acting in an environmentally responsible, economically feasible and politically strategic manner through mitigating their GHG emissions. In the effort to address climate change issues, power utilities are focusing on adopting clean and efficient technologies for power plants, proactively embracing renewable energy ( $\mathrm{RE})$, developing innovative solutions and research, adopting the energy efficiency. Based on Table 6 below, there are three measures identified as carbon mitigation measures which have contributed about to 5.03 million $\mathrm{tCO}_{2} \mathrm{e}$ mitigated from the atmosphere.

Table 6

GHG Emissions Mitigation

\begin{tabular}{ll}
\hline Programme & $\mathrm{tCO}_{2} \mathrm{eq}$ \\
\hline Large Hydro & $3,597,007$ \\
Renewable Energy & 8,965 \\
Clean Coal Technology & $1,421,569$ \\
TOTAL & $5,027,541$ \\
\hline
\end{tabular}

Based on Table 6 above, large scale hydropower contributed the largest reduction in GHG emissions of up to $71.5 \%$ from the total figure in 2017, whereas Clean Coal Technology (CCT) came in second, comprising $28.3 \%$ of the total figure. This mitigation of GHG emissions would not have happened without hydropower generation since the same amount of electricity would have to replace with the continued generation of electrical energy from thermal power plants.

The potential GHG mitigation up to the year 2025 was also calculated to identify potential emission reduction and emission target. The potential emission mitigation is based on the projection of electricity generation (obtained from Single Buyer) and the expected addition of new power plants. By deriving the result from the first and second steps (Assessment of GHG emission, GHG mitigation measures), the assessment has derived benchmarking values that will serve as the values to compare with future projections.

Three (3) key scenarios were assessed to provide recommendations for the best combination of mitigation strategies up to 2025. In the first scenario, Business-As-Usual (BAU) the GHG emissions are projected based on no additional policy intervention from 2018 until 2025, by referring to historical development trends and future generation planning. The second scenario, Planning (PLAN), takes into account the existing future internal policies and plans within the period of projection to map the potential GHG emission mitigation within the period. The third and final scenario, Ambitious $(A M B)$, looks at potential emissions reduction by introducing additional mitigation measures on top of the planned measures included in the second scenario. Based on the analysis, the projection indicates that the total emissions would be 36.96 million $\mathrm{tCO}_{2}$ e for the $\mathrm{BAU}$ case by 2025 (Figure 2). Continued implementation of planned activities under the PLAN scenario would bring emissions down by 3.93 million $\mathrm{tCO}_{2} \mathrm{e}$. If further mitigation activities under the AMB scenario are carried out, emissions could reduce further by 7.52 million $\mathrm{tCO}_{2} \mathrm{e}$. In tandem with the reduction of $\mathrm{GHG}$ emissions across the various scenarios, the emission intensity will also become lower (Table 7). 


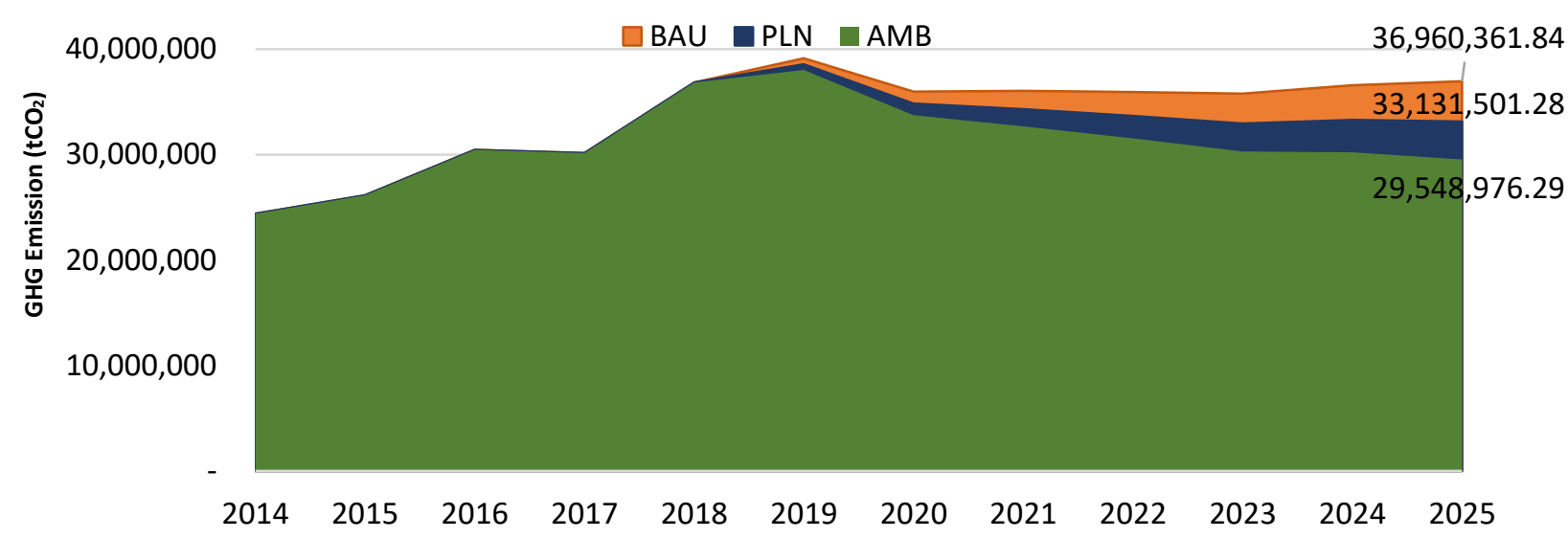

Fig. 2. Projected GHG Emission up to 2025 - All Three Scenarios (Business-As-Usual, Planned, and Ambitious)

\begin{tabular}{|c|c|c|c|}
\hline Scenario & $\begin{array}{l}\text { Projected Power Generation } \\
\text { (MWh) }\end{array}$ & $\begin{array}{l}\text { Projected Carbon Emission } \\
\left(\mathrm{tCO}_{2} \mathrm{e}\right)\end{array}$ & $\begin{array}{l}\text { Emission Intensity } \\
\left(\mathrm{tCO}_{2} \mathrm{e} / \mathrm{MWh}\right)\end{array}$ \\
\hline BAU & $46,404,674.49$ & $36,960,361.84$ & 0.796 \\
\hline PLN & $66,888,952.44$ & $33,131,501.28$ & 0.495 \\
\hline AMB & $66,888,952.44$ & $29,548,976.29$ & 0.442 \\
\hline
\end{tabular}

Since the power generation activities contributed the most in GHG emission, the largest mitigation impact can be achieved through optimization and increasing efficiency of that sector. The Electricity Supply Industry (ESI) needs to balance and optimize in accordance with energy trilemma; i.e., energy security, economics, and social impact. In the near and mid-term, full transition/ adoption of renewable energies is considered unlikely due to various challenges. Hence utilities need to think of interim measures/ initiatives. Hence, In the near to medium term, power utility can consider different options to reduce its GHG emission through charting/ planning its power generation operation and fleet; firstly by focusing on cleaner energy resources, i.e., large hydro and more efficient combined cycle gas power plant. Secondly by reducing the number of coal power plant in future development, thirdly by repowering old power plants with cleaner gas and hydropower plant, and fourthly in the event that new coal power plant is still required, more advanced and cleaner coal power technology needs to be implemented (e.g., ultra-supercritical, or advanced ultra-supercritical technologies).

\section{Conclusions}

From this study, it can conclude that the type of fuel consumed by the power plant will contribute to the total GHG emissions. The GHG emission assessment result under this shows that $64 \%$ of GHG emission came from coal consumption which consists of high carbon content compared to natural gas and distillate. Therefore, it is important for the power utility and authority to relook at generation fuel mix and installed capacity to reduce the GHG emissions in the future effectively.

In addition, the generation efficiency, fuel selection, technology and another factor such as plant age contribute to the power plant GHG emissions. It can generally be observed that GHG emission intensity for the selected power under this study ranges from $0.540 \mathrm{tCO}_{2} \mathrm{e} / \mathrm{MWh}$ to 0.560 $\mathrm{tCO}_{2} \mathrm{e} / \mathrm{MWh}$, depending on $\mathrm{GHG}$ emissions per unit of electricity generation output for the particular year. 
Based on the GHG mitigation assessment, it was learned that the utilization of large hydro and natural gas in power generation could help in reducing GHG emission as the energy source is cleaner and less carbon intensive. The various scenarios (BAU, PLAN, and AMB) indicates that power utility can reduce its future GHG emissions through various initiatives. The best scenario in $\mathrm{GHG}$ emission mitigation is $A M B$, where it estimated that power utility would be able to reduce its GHG level by $\sim 20 \%$ in comparison with the BAU scenario. As such, power utility needs to find the balance and optimization in its infrastructure and business development to address the impact of energy trilemma effectively (energy security, environment and social). The scenarios are just a forecasting indicator that predicts/visualize what will the emission situation looks like, that helps in future strategy and planning.

Apart from that, the assessment of GHG emission scenario needs to be consistently updated aligning with the changes of regulatory and enablers (such as economics, technological advancement) to predict the future scenario and take the correct approach/ strategy in making power utility company more prepared in facing challenges and opportunities. Furthermore, education must also be conducted to inculcate low carbon awareness in fostering a low carbon society [17].

\section{References}

[1] KeTTHA. Green Technology Master Plan Malaysia 2017-2030. Ministry of Energy, Green Technology and Water, Putrajaya, Malaysia. 2017.

[2] Economic Planning Unit. National Transformation Programme. Economic Planning Unit, Prime Minister's Department, Putrajaya, Malaysia, 2010.

[3] Suruhanjaya Tenaga (Energy Commission). National Energy Balance 2000. Suruhanjaya Tenaga, Putrajaya, Malaysia, 2002.

[4] Suruhanjaya Tenaga (Energy Commission). National Energy Balance 2016. Suruhanjaya Tenaga, Putrajaya, Malaysia, 2018.

[5] KeTTHA. Malaysia's Third National Communication and Second Biennial Update Report. Ministry of Energy, Science, Technology, Environment and Climate Change, Putrajaya, Malaysia, 2018.

[6] United Nation Framework Convention on Climate Change (UNFCCC). Nationally Determined Contributions (NDCs). United Nations Climate Change, 2015.

[7] Saba, Liman Alhaji, Mohd Hamdan Ahmad, Roshida Abdul Majid, and Ahmed Yahaya. "Material and assembly selection: Comparative analysis of embodied energy and carbon as an index for environmental performance." Journal of Advanced Research in Materials Science 44, no. 1 (2018): 1-24.

[8] Eggleston, Simon, Leandro Buendia, Kyoko Miwa, Todd Ngara, and Kiyoto Tanabe. 2006 IPCC Guidelines for National Greenhouse Gas Inventories: Volume 2 Energy. Institute for Global Environmental Strategies (IGES), Japan, 2006.

[9] Suruhanjaya Tenaga (Energy Commission). Peninsular Malaysia Electricity Supply Industry Outlook 2016. Suruhanjaya Tenaga, Putrajaya, Malaysia, 2015.

[10] Suruhanjaya Tenaga (Energy Commission). Peninsular Malaysia Electricity Supply Industry Outlook 2017. Suruhanjaya Tenaga, Putrajaya, Malaysia, 2017.

[11] Shires, Theresa M., Christopher J. Loughran, Stephanie Jones, and Emily Hopkins. Compendium of Greenhouse Gas Emissions Methodologies for the oil and natural gas Industry. American Petroleum Institute, 2009.

[12] United Nation Framework Convention on Climate Change. ACM0002: Grid-connected electricity generation from renewable sources. Version 19.0. Clean Development Mechanism (CDM) UNFCC, 2018.

[13] United Nation Framework Convention on Climate Change. AMS-I.D.: Grid connected renewable electricity generation. Version 18.0. Clean Development Mechanism (CDM) UNFCC, 2014.

[14] Eggleston, Simon, Leandro Buendia, Kyoko Miwa, Todd Ngara, and Kiyoto Tanabe. 2006 IPCC Guidelines for National Greenhouse Gas Inventories: Volume: Agriculture, Forestry and Other Land Use. Institute for Global Environmental Strategies (IGES), Japan, 2006.

[15] Malaysian Green Technology Corporation. Study on Grid Connected Electricity Baselines in Malaysia 2014. Malaysian Green Technology Corporation (MTGC), Putrajaya, Malaysia, 2015.

[16] Asian Development Bank. Guidelines for estimating greenhouse gas emissions of Asian Development Bank projects: Additional guidance for clean energy projects. Asian Development Bank (ADB), 2017. 
[17] Phang, Fatin Aliah, W. Wai Yoke, H. Chin Siong, Maiko Suda, and Junichi Fujino. "A Successful Model to Inculcate Low Carbon Awareness among School Students and Teachers." Journal of Advanced Research Design 12, no. 1 (2015): 21-34. 